\title{
Efektivitas Hipoglikemik Fraksi Etil Asetat Ampas Tahu menggunakan Model Hewan Ikan Zebra (Danio rerio)
}

Hypoglycemic Activity of Ethyl Acetate Fraction of Tofu Residue Using Danio rerio as an Animal Model

\author{
Penulis $\quad$ Nina Herlina ${ }^{1}{ }^{*}$, Mulyati $^{1}$, Yulianita $^{1}$, Putri Ananda $^{1}$ \\ Afiliasi $\quad{ }^{1}$ Fakultas Matematika dan Ilmu Pengatahuan Alam, Universitas Pakuan, Jawa Barat, \\ 16144, Indonesia
}

\section{Kata Kunci \\ ○ ampas tahu \\ $\rightarrow$ hipoglikemik \\ glukosa darah \\ $\rightarrow$ isoflavon \\ ○ Danio rerio}

\section{Keywords \\ - blood glucose levels \\ $\rightarrow$ hypoglycaemic \\ - Isoflavones \\ $\rightarrow$ tofu residue \\ $\rightarrow$ Danio rerio}

Diterima 26 Agustus 2019 Direvisi 16 Oktober 2019 Disetujui 16 April 2020

*Penulis Koresponding Nina Herlina email:

nina.herlina@unpak.ac.id

\section{ABSTRAK}

Ampas tahu mengandung isoflavon genistein dan daidzein yang diduga memiliki efek hipoglikemik. Penelitian ini bertujuan untuk menguji efek hipoglikemik fraksi etil asetat ampas tahu (FEAAT). Ekstraksi isoflavon ampas tahu dilakukan dengan metode refluks menggunakan etanol dan $\mathrm{HCl}$, kemudian fraksinasi menggunakan etil asetat. Efek hipoglikemik FEAAT dibuktikan menggunakan ikan zebra sebagai hewan uji. Kelompok perlakuan terdiri dari kontrol negatif (akuades), FEAAT1 dan FEAAT2 dengan konsentrasi $3,75 \%$ dan $5 \%$ serta kontrol positif (metformin). Hiperglikemia diinduksi dengan perendaman menggunakan aloksan $0,05 \%$ selama 30 menit, glukosa $1 \%$ selama 30 menit. Selanjutnya dilakukan pemberian sampel uji selama 120 menit secara berurutan untuk menguji efek hipoglikemik dari sampel uji. Cuplikan darah diambil pada menit ke-0, 30, 60, 90, dan 120 untuk diuji kadar glukosa darah. Hasil uji menunjukkan bahwa terdapat perbedaan yang nyata pada luas Area Under Curve $\left(\mathrm{AUC}_{0-120}\right)$ kontrol negatif dengan FEAAT2 dan metformin $(p<0,01)$. Sementara hasil nilai AUC $_{0-120}$ FEAAT1 tidak berbeda nyata dengan kontrol negatif. FEAAT2 efektif sebagai agen hipoglikemik pada model hewan ikan zebra yang diinduksi hiperglikemik.

\section{ABSTRACT}

Tofu residue contain isoflavones genistein and daidzein. Which are thought to be responsible for the hypoglycemic effect. The aim of this study was to determine the hypoglycemic effect of ethyl acetate fraction tofu residue (FEAAT). Extraction isoflavone of tofu residue was conducted by reflux method using ethanol and $\mathrm{HCl}$, then fractionation used ethyl acetate. The hypoglycemic effect of FEAAT was verified using zebrafish as an animal test. The treatment group consisted of water as negative control, FEAAT1 and FEAAT1 concentration of $3.75 \%$ and $7.5 \%$, respectively, and metformin as positive control. Hyperglycemia in the fish was induced by soaking them in alloxan $0.05 \%$ for $30 \mathrm{~min}$, glucose 0,1\% for $30 \mathrm{~min}$, and tested sample for $60 \mathrm{~min}$ in sequence. The blood glucose level was measured every 30 minutes for 2 hours. The results showed that significantly differences in the area of the Under-Curve Area $\left(A \cup C_{0-120}\right)$ between negative control with FEAAT2 and metformin ( $p<0.01)$. While the FEEAT1 was not significantly different than negative controls. FEAAT2 effective as hypoglycemic agent at hyperglycemic zebrafish model. 


\section{PENDAHULUAN}

Sekitar $8,3 \%$ orang dewasa di dunia (382 Juta orang) menderita diabetes mellitus dan peningkatan yang dramatis di negara-negara seluruh dunia (IDF 2015). Jumlah ini diprediksi akan meningkat secara dramatis di tahun-tahun mendatang, menghasilkan tantangan kesehatan dan ekonomi yang serius. Diabetes melitus (DM) merupakan gangguan metabolisme kronis dengan multi etiologi yang ditandai dengan tingginya kadar gula darah disertai dengan gangguan metabolisme karbohidrat, lipid dan protein sebagai akibat insufisiensi fungsi insulin (Dipiro et al. 2008).

Hiperglikemia diperkirakan menjadi salah satu faktor utama yang berkontribusi terhadap komplikasi DM termasuk penyakit yang mempengaruhi sistem kardiovaskular dan saraf, mata atau ginjal. Setiap tahun, 4,9 juta orang meninggal akibat DM (IDF 2015) sekitar $50 \%$ dari pasien dengan komplikasi kardiovaskular. Risiko komplikasi DM dapat dikurangi secara efektif. Indonesia memiliki potensi ampas tahu (AT) cukup tinggi, karena produksi kedelai mencapai 779.074 ribu ton pada tahun 2012 (BPS 2012), hal ini berpengaruh pada produksi tahu yang menggunakan bahan baku kedelai. Pada industri-industri pembuatan tahu, ampas tahu dianggap sebagai limbah yang tidak bernilai ekonomis sehingga biasanya dibuang tanpa diolah lebih lanjut untuk dijadikan produk bernilai ekonomis. Menurut Balai Penelitian dan Pengembangan Industri yang dikutip oleh Arbaiyah (2003), industri tahu di Indonesia sebagian besar masih melakukan pengolahan secara sederhana sehingga kandungan bermanfaat yang terdapat di ampas tahu masih cukup banyak. Hal ini dibuktikan oleh penelitian yang dilakukan oleh Sulistiani (2004) dimana dalam tepung ampas tahu mengandung protein $(11,04 \%)$, lemak $(19,69 \%)$, karbohidrat $(51,50 \%)$, serat pangan tidak larut $(42,75 \%)$ dan serat pangan larut $(8,75 \%)$. Selain kandungan tersebut, ampas tahu juga terbukti masih mengandung isoflavon berupa genistein dan daidzein meskipun kandungannya setengah dari kandungan isoflavon yang terdapat pada kedelai (Jannatun 2009).

Kandungan isoflavon pada ampas tahu diduga memiliki peranan dalam regulasi glukosa darah. Bhattamisra et al. (2013) dan Babu et al. (2013) serta Cheong et al. (2014) mengkonfirmasi bahwa isoflavon dari kedelai dapat membantu memperbaiki kondisi hiperglikemia. Akan tetapi belum ada yang mengkonfirmasi efek isoflavone yang terdapat pada ampas tahu sebagai agen hipoglikemik. Oleh karena itu dalam penelitian ini dilakukan pengujian efek hipoglikemik pada ampas fraksi etil asetat ampas tahu terhadap ikan zebra. Ikan zebra digunakan sebagai hewan percobaan dengan berbagai pertimbangan yaitu, ikan zebra memiliki kesamaan genetik dan psikologi dengan mamalia dan dinilai cukup baik digunakan sebagai model hewan diabetes (Shin et al. 2012). Dari hasil penelitian ini diharapkan nilai guna ampas tahu semakin meningkat dan komoditas ampas tahu semakin berkembang sehingga meningkatkan pendapatan produsen tahu.

\section{METODE}

\section{Alat dan Bahan}

Alat yang digunakan adalah akuarium, glukometer (Easy touch, Miaoli County, Taiwan), strip test glukosa (Accu check, indianapolis, USA). Bahan yang digunakan ampas tahu (Pabrik Tahu Sumedang Bumi Armasta, Bogor, Indonesia), etanol $70 \%, \mathrm{HCl} 4 \mathrm{~N}$, etil asetat, kloroform, $\mathrm{NH}_{4} \mathrm{OH}, \mathrm{H}_{2} \mathrm{SO}_{4} 2 \mathrm{M}$, serbuk magnesium, alkohol, akuades, $\mathrm{FeCl}_{3} 1 \%$, metanol, pakan (Tetramin, Blacksburg, USA), Metformin (Hexapharm Jaya, Jakarta, Indonesia), aloksan 0.1\% (Sigma Aldrich, St Louis, USA), glukosa $1 \%$, es batu, tissue. Ikan zebra (Danio rerio) yang berumur sekitar 118 hari dengan ukuran M (1-1.5 inci) sebanyak 120 ekor diperoleh dari petani ikan di daerah Cibinong, Bogor Indonesia.

\section{Ekstraksi dan Fraksinasi Ampas Tahu}

Ampas tahu segar dikeringkan menggunakan vacuum dryer hingga diperoleh ampas tahu kering. Setelah itu dilakukan ekstraksi dengan metode refluks. Sampel ampas tahu sebanyak $1 \mathrm{~kg}$ direfluks menggunakan campuran $\mathrm{HCl} 4 \mathrm{~N}$ dan etanol dengan perbandingam $1: 8$ selama 2 jam pada suhu $70^{\circ} \mathrm{C}$. Campuran disaring dengan menggunakan pompa vakum dan kertas saring Whatman nomor 41 . Filtrat yang diperoleh kemudian dipekatkan menggunakan rotavapor. Ekstrak ampas tahu difraksinasi dengan etil asetat (1:1) menggunakan corong pisah. Fraksi etil asetat yang diperoleh kemudian disaring, dan dipekatkan dengan rotavapor.

\section{Uji Mutu dan Uji Fitokimia}

Sampel uji yang diperoleh dianalisis meliputi kadar air, kadar abu dan uji fitokimia. Metode Pengecekan kadar air mengacu pada Materia Medika (Depkes 1995), kadar abu mengacu pada Parameter Standar Umum Ekstrak Tumbuhan Obat (Depkes 2000) serta uji fitokimia mengacu pada Harborne (1987). 


\section{Pembuatan Pakan Jamu}

Pakan kering dimasukkan ke dalam tabung plastik, kemudian sampel uji ditambahkan ke dalam pakan sedikit demi sedikit sambil terus diaduk. Variasi nisbah pakan: FEAAT yaitu 1:0,3, 1:0,6, 1:0,9 sementara nisbah pakan: metformin adalah 1:0,6 (Littleton et al. 2012).

\section{Persiapan dan Pemeliharaan Ikan Zebra}

Persiapan dan Pemeliharaan ikan zebra sebagai hewan uji mengacu pada Avdesh et al. (2012) melalui persetujuan Komite Etik Penggunaan Hewan FMIPA UNPAK dengan SK No.2/KEPH-UNPAK/3-2019. Jenis ikan zebra yang digunakan ialah ekor panjang, warna abu-abu dengan garis metalik yang melintang sepanjang badan hingga ekor. Semua ikan zebra disesuaikan dengan kondisi laboratorium yang konstan (14 jam cahaya: 10 jam gelap, diet) selama setidaknya satu minggu di akuarium persediaan sebelum percobaan dilakukan. Ikan diberi makan dua kali sehari dengan pakan komersil Tetramin sebanyak 4\% BB /ekor/hari. Semua ikan zebra yang digunakan dalam percobaan ini adalah ikan dewasa yang dipilih secara acak. Setelah kondisi ruangan dan akuarium siap, ikan zebra ditempatkan dalam 7 akuarium dengan ukuran $30 \times 25 \times 25 \mathrm{~cm}^{3}$ masing-masing sebanyak 25 ekor lalu dilakukan masa adaptasi selama 1 minggu.

\section{Uji Efektivitas Hipoglikemik FEAAT}

Induksi hiperglikemik akut mengacu pada penelitian Shin et al. (2012) dengan adanya modifikasi waktu yaitu perendaman dengan aloksan 0,05\% (b/v) dalam $\mathrm{NaCl}$ $0,45 \%$ selama 30 menit, perendaman glukosa $1 \%$ selama 30 menit, kemudian perendaman dengan akuades yang mengandung larutan uji selama 120 menit. Pembagian kelompok uji sebagaimana tertera pada Tabel 1. Pengukuran kadar gula darah dilakukan pada menit ke-30,60, 90, dan 120. Pengukuran kadar glukosa darah dilakukan dengan memindahkan ikan zebra ke dalam wadah berisi air dingin dengan suhu yang diturunkan secara perlahan dari $17^{\circ} \mathrm{C}$ menjadi $12^{\circ} \mathrm{C}$ dengan tujuan membuat ikan pingsan. Ikan yang sudah pingsan dikeluarkan dari larutan, ditepuk dan keringkan dengan tisu. dan ditempatkan di permukaan keramik dengan posisi ikan melintang. Darah diperoleh dengan memotong bagian ekor ikan menggunakan pisau tajam. Sampel darah ditempelkan pada glukometer yang akan secara otomatis menyerap darah (Capiotti et al. 2014).

\section{Analisis Data}

Data kadar glukosa darah ikan zebra dinyatakan sebagai rata-rata \pm SD. Efektivitas hipoglikemik dinyatakan dengan kadar glukosa darah (rata-rata \pm SD) dan nilai Area Under Curve ${ }_{0-120}\left(\mathrm{AUC}_{0-120}\right)$. Data $\mathrm{AUC}_{0-120}$ dianalisis secara statistika dengan metode analisis keragaman (one way anova) menggunakan uji lanjut Duncan dengan tingkat kepercayaan $95 \%$.

Tabel 1. Kelompok Pemberian Perlakuan

\begin{tabular}{cl}
\hline Kelompok & \multicolumn{1}{c}{ Perlakuan } \\
\hline I & Kontrol negatif, Induksi + akuades \\
II & Kontrol positif, Induksi + Metformin $(7,5 \% \mathrm{~b} / \mathrm{v})$ \\
III & Dosis I, Induksi + fraksi etil asetat ampas tahu $(3,75 \% \mathrm{~b} / \mathrm{v})$ \\
IV & Dosis II, Induksi + fraksi etil asetat ampas tahu $(7,5 \% \mathrm{~b} / \mathrm{v})$ \\
\hline
\end{tabular}

Keterangan: *Dosis perbandingan pakan: sampel berdasarkan Littleron et al. (2012) yang dimodifikasi, yaitu perbandingan pakan dengan bahan uji 1:0,6 kemudian dilarutkan dalam $500 \mathrm{~mL}$ air sehingga konsentrasinya menjadi $7,5 \% \mathrm{~b} / \mathrm{v}$.

Tabel 2. Kadar Air dan Kadar Abu Ampas Tahu

\begin{tabular}{|c|c|c|c|c|}
\hline Uji Karakteristik & Sampel & Hasil & Rata-rata & Standar \\
\hline \multirow{4}{*}{ Kadar Air } & \multirow{2}{*}{ Serbuk kering } & $10,38 \%$ & \multirow{2}{*}{$10,95 \%$} & \multirow{4}{*}{$\leq 10 \%$} \\
\hline & & $11,53 \%$ & & \\
\hline & \multirow{2}{*}{ Ekstrak etanol } & $34,58 \%$ & \multirow{2}{*}{$35,37 \%$} & \\
\hline & & $36,17 \%$ & & \\
\hline \multirow{4}{*}{ Kadar Abu } & \multirow{2}{*}{ Serbuk kering } & $1,95 \%$ & \multirow{2}{*}{$10,95 \%$} & \multirow{4}{*}{$\leq 16$} \\
\hline & & $1,93 \%$ & & \\
\hline & \multirow{2}{*}{ Ekstrak etanol } & $13,52 \%$ & \multirow{2}{*}{$12,79 \%$} & \\
\hline & & $12,07 \%$ & & \\
\hline
\end{tabular}

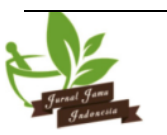


Tabel 3. Hasil Uji Fitokimia Ampas Tahu

\begin{tabular}{lcc}
\hline \multicolumn{1}{c}{ Senyawa } & Serbuk Ampas Tahu & Ekstrak Etanol Ampas Tahu \\
\hline Alkaloid & + & - \\
Flavonoid & + & + \\
Tanin & + & + \\
Saponin & - & - \\
\hline
\end{tabular}

Tabel 4. Rata-rata kadar glukosa darah ikan zebra (mean $\pm s d)$

\begin{tabular}{llllll}
\hline \multirow{2}{*}{ Kelompok } & \multicolumn{5}{c}{ Kadar Glukosa Darah (mg/dl) pada menit ke- } \\
\cline { 2 - 5 } & \multicolumn{1}{c}{$\mathbf{0}$} & \multicolumn{1}{c}{$\mathbf{3 0}$} & $\mathbf{6 0}$ & \multicolumn{1}{c}{$\mathbf{9 0}$} & \multicolumn{1}{c}{$\mathbf{1 2 0}$} \\
\hline Kontrol Negatif & $28,67 \pm 13,05$ & $158,67 \pm 50,54$ & $84,67 \pm 44,52$ & $51,00 \pm 23,06$ & $51,67 \pm 2,08$ \\
Metformin & $25,75 \pm 13,60$ & $58,25 \pm 24,80$ & $47,75 \pm 27,28$ & $35,25 \pm 9,87$ & $26,00 \pm 5,56$ \\
FEAAT1 & $28,00 \pm 24,04$ & $93,00 \pm 10,23$ & $50,00 \pm 37,38$ & $32,75 \pm 10,82$ & $36,67 \pm 22,03$ \\
FEAAT2 & $24,67 \pm 7,05$ & $56,00 \pm 14,14$ & $26,50 \pm 3,69$ & $57,25 \pm 37,07$ & $28,25 \pm 8,01$ \\
\hline
\end{tabular}

\section{HASIL DAN PEMBAHASAN}

Kadar Air, Kadar Abu dan Kandungan Fitokimia Ekstrak Ampas Tahu

Ampas tahu kering mengandung kadar air 10,45\% dan kadar Abu sebesar 10,95\%. Setelah diekstraksi dengan etanol $70 \%$ dan $\mathrm{HCl}$ kadar air ampas tahu $35,37 \%$ dan kadar abu $12,79 \%$ sebagaimana ditunjukkan pada Tabel 2. Ekstrak ampas tahu mengandung flavonoid dan tanin sebagaimana ditunjukkan pada Tabel 3.

\section{Efektivitas Hypoglikemik Fraksi Ampas Tahu}

Kadar glukosa darah ikan zebra diukur pada menit ke-0, 30, 60, 90 dan 120. Hasil pengukuran KGD dapat dilihat pada Tabel 4.

Tabel 4 menunjukkan bahwa semua kelompok mengalami kenaikan kadar glukosa darah pada menit ke-30, akan tetapi kenaikan tertinggi terjadi pada kontrol negatif, sekitar 6 kali lipat dari kondisi awal. Pada menit ke-60 semua kelompok mengalami penurunan KGD, akan tetapi pada menit ke-90 kelompok FEEAT2 mengalami kenaikan KGD. Namun pada menit ke-120 terjadi penurunan KGD dengan nilai KGD mendekati nilai awal. Nilai KGD kelompok Metformin juga mengalami penurunan pada menit ke120 mendekati nilai KGD normal, kecuali pada kelompok negatif dan FEAAT1. AUC $\mathrm{A}_{0-120}$ digunakan sebagai gambaran efek hipoglikemik dari fraksi etilasetat ampas tahu (FEAAT). Semakin kecil nilai $\mathrm{AUC}_{0-120}$ maka efek hipoglikemik semakin besar. Data $\mathrm{AUC}_{0-120}$ dapat dilihat pada Gambar 1.
Gambar 1 menunjukkan bahwa kelompok Metformin memiliki Nilai $\mathrm{AUC}_{0-120}$ paling kecil diantara semua kelompok, kemudian FEEAT2, FEEAT1 dan yang terbesar adalah kelompok negatif. Hasil uji statistik menggunakan ANOVA diketahui bahwa perlakuan memberikan pengaruh yang nyata terhadap nilai $A \cup C_{0}$ ${ }_{120}$ ( $P$ Value 0,009 ). Perbedaan respon yang nyata ini ditunjukkan oleh kelompok FEEAT2 dan Metformin terhadap kelompok negatif $(P$ Value $=0,001)$. Hal tersebut menunjukkan bahwa kedua kelompok tersebut memiliki kemampuan sebagai agen hipoglikemik. FEAAT1 memiliki nilai AUC $_{0-120}$ lebih kecil dibandingkan kontrol negatif, akan tetapi hasil uji analisis menunjukkan belum ada perbedaan yang nyata ( $P$ Value $=0,16)$, sehingga dapat dikatakan bahwa FEAAT1 belum memiliki kemampuan sebagai agen hipoglikemik.

Penelitian ini menggunakan ikan zebra sebagai model hewan hiperglikemia dengan memodifikasi metode induksi Shin et al (2012). Hiperglikemia adalah suatu kondisi di mana tingginya kadar glukosa dalam plasma darah (Lim 2013). Ikan zebra direndam di dalam larutan aloksan 0,05\% (b/v) dalam $\mathrm{NaCl} 0,45 \%$ selama 30 menit, dilanjutkan peremdaman dalam glukosa $1 \%$ selama 30 menit dan perendaman dalam akuades yang mengandung larutan uji selama 120 menit. Shin et al (2012) menyatakan bahwa setelah dilakukan induksi tersebut, ikan zebra mengalami kondisi hiperglikemia akut. Model semacam ini dibuat untuk eksperimen jangka pendek, dan penelitian lebih lanjut diperlukan untuk mengembangkan model zebrafish hiperglikemia permanen (Lee et al. 2011). 


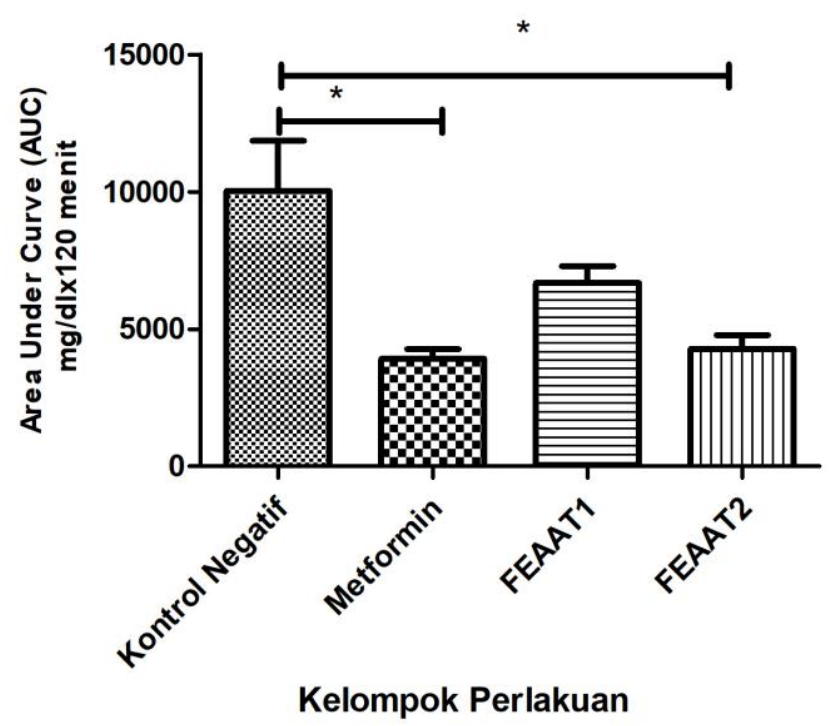

Gambar 1. Area di bawah kurva $\left(\mathrm{AUC}_{0-120}\right)$. Kumpulan data yang ditampilkan adalah perwakilan dari tiga percobaan. Data direpresentasikan sebagai rata-rata \pm SD ( $n=3 /$ grup). ${ }^{*} \mathrm{P}<0,05$ vs kontrol negatif

Hasil penelitian ini menunjukkan bahwa fraksi etil asetat ampas tahu konsentrasi $7,5 \% \mathrm{~b} / \mathrm{v}$ (FEAAT2) terbukti dapat menurunkan kondisi hiperglikemia pada ikan zebra. Efek penurunan kadar glukosa ini diduga karena kandungan senyawa yang dimiliki. Ampas tahu dilaporkan mengandung isoflavon berupa genistein dan daidzein (Arbaiyah (2003) dan Jannatun (2009)). Kandungan ini diduga menjadi salah satu yang berperanan dalam menurunkan kadar glukosa darah. Beberapa penelitian menyatakan bahwa Isoflavon baik genistein dan daidzein memiliki peranan penting dalam regulasi glukosa darah. Bhattamisra et al (2013) dan Babu et al. (2013) melaporkan bahwa isoflavon kedelai terbukti dapat memperbaiki toleransi glukosa oral dan memperbaiki toleransi insulin. Gilbert \& Liu (2013) juga telah menunjukkan bahwa genistein adalah agen antidiabetogenik melalui efeknya pada proliferasi sel- $\beta$ dan sekresi insulin oleh stimulasi glukosa terlepas dari efisiensinya sebagai antioksidan. Selain itu, Cheong et al. (2014) mengkonfirmasi bahwa daidzein dapat meningkatkan ambilan glukosa dalam adiposit dan sel otot serta dapat menekan peningkatan glukosa dalam serum.

Selain itu, ampas tahu juga mengandung antioksidan yang dapat berperan kuat dalam pengendalian diabetes mellitus Ampas tahu juga mengandung tanin (Tabel 3). Tanin mempunyai aktivitas hipoglikemik dengan mekanisme meningkatkan glikogenesis dan berfungsi sebagai pengkhelat yang dapat mengerutkan membran epitel usus halus sehingga mengurangi penyerapan sari makanan dan sebagai akibatnya menghambat asupan glukosa sehingga laju peningkatan glukosa darah tidak terlalu tinggi (Tandi et al. 2007).

\section{SIMPULAN}

Fraksi etil asetat ampas tahu konsentrasi 7,5\% (FEAAT2) efektif sebagai agen hipoglikemik pada model ikan zebra (Danio rerio).

\section{UCAPAN TERIMAKASIH}

Penulis mengucapkan terima kasih sebanyakbanyaknya kepada LPPM Universitas Pakuan yang telah memberikan support pendanaan kepada penulis.

\section{DAFTAR PUSTAKA}

Arbaiyah, Ita. 2003. Kandungan Protein dan Kalsium serta Daya Terima Susu Kedelai yang dibuat dari Ampas Tahu dengan Penambahan Bahan Pengental [Skripsi]. Medan (ID). Universitas Sumatera Utara.

Avdesh A, Chen M, Martin-Iverson MT, Mondal A, Ong D, Rainey-Smith S, Taddei K, Lardelli M, Groth DM, Verdile G, Martins RN. 2012. Regular care and maintenance of a zebra Fish (Danio rerio) laboratory: an introduction. J. Vis. Exp. 69(4196):18.

Babu PV, Liu D, Gilbert ER. 2013. Recent advances in understanding the anti-diabetic actions of dietary flavonoids. J Nutr Biochem.; 24(11):1777-89. 
Badan Pusat Statistik (BPS). 2012. Pola-pertanianjagung-kedelai-dan-kacang-tanahkabupaten-pati2012 [internet]. Diakses tanggal 27 Oktober 2018.www. patikab.bps.go.id

Bhattamisra, Subrat \& Mohapatra, L \& Panda, B \& Parida, S. 2014. Effect of Isoflavone rich Soya seed extract on glucose utilization and endurance capacity in diabetic rat. Diabetologia Croatica. 42. 42.

Capiotti KM, Junior RA, Kist LW, Bogo RM, Bonan CD, Silva RSD. 2014. Persistent impaired glucose metabolism in a zebrafish hyperglycemia model. Comparative Biochemistry and Physiology. 171: 5865.

Cheong, S. H., Furuhashi, K., Ito, K., Nagaoka, M., Yonezawa, T., Miura, Y., Yagasaki K. 2014. Daidzein promotes glucose uptake through glucose transporter 4 translocation to plasma membrane in L6 myocytes and improves glucose homeostasis in Type 2 diabetic model mice. J. Nutr. Biochem. 25, 136-143.

Depkes RI. 1995. Materia Medika Indonesia, Jilid VI. Jakarta (ID) : Departemen Kesehatan Republik Indonesia.

Depkes RI. 2000. Parameter Standar Umum Ekstrak Tumbuhan Obat. Jakarta (ID): Direktorat Jendral Pengawasan Obat dan Makanan.

Dipiro, J. T., Talbert R. L., Yee G. C., Matzke G. R., Wells B. G dan Posey L. M. 2008 Pharmacotherapy - A Pathophysiologic Approach 7th ed. New York (USA): McGraw Hill Medical, 1220-1227.

Gilbert, E.R. \& Liu, D. 2013. Anti-diabetic function of soy isoflavone genistein: mechanism underlying its effects on pancreatic beta-cell function. Food and Function. 4 (2): 200-212.

Harborne, J.B. 1987. Metode Fitokimia Penuntun Cara Modern Menganalisa Tumbuhan. Bandung (ID): ITB.
International Diabetes Federation. 2015. IDF Diabetes Atlas, 7th edn. International Diabetes Federation [internet]. Diakses pada tanggal 17 Maret 2019. Edisi 7. http://www.diabete satlas.org

Jannatun,R. 2009. Kadar Genistein Dan Daidzein Pada Kedelai, Ampas Tahu, Dan Oncom Merah [Skripsi]. Bogor (ID): Insitut Pertanian Bogor.

Lee JH, Yang SH, Oh JM, Lee MG. 2011. Pharmacokinetics of drugs in rats with diabetes mellitus induced by alloxan or streptozocin: Comparison with those in patients with type I diabetes mellitus. J. Pharm. Pharmacol. 62:1-23.

Lim, T.K. 2013. "Edible Medicinal and Non-Medicinal Plants: Volume 6, Fruits". Newyork (USA): Springer.

Littleton, Robert M., Matthew Miller and Jay R. Hove. 2012. Whole plant based treatment of hypercholesterolemia with Crataegus laevigata in a zebrafish model. BMC complementary and alternative medicine. 12:105 Doi: 10.1186/14726882-12-105.

Shin E, Hong B N, and Kang T H. 2012. An optimal establishment of acute hyperglicemia ikan zebra model. African Journal of Pharmacy and Pharmacology. 6(42):2922-2928.

Sulistiani. 2004. Pemanfaatan Ampas Tahu dalam Pembuatan Pangan Tinggi Serat dan Protein sebagai Alternatif Bahan Baku Pangan Fungsional [Skripsi]. Bogor (ID). Fateta IPB.

Tandi, J., H Z, M., Yuliet, Y., \& Yusriadi, Y. 2016. Efektivitas Ekstrak Daun Gedi Merah terhadap Glukosa Darah, Malondialdehid, 8-HdroksiDeoksiguanosin, Insulin Tikus Diabetes. Journal of Tropical Pharmacy and Chemistry, 3(4), 264-276. https://doi.org/10.25026/jtpc.v3i4.114 